\title{
Challenges Facing the Use of Human Rights to Address Negative Impacts of Development: The Case of Indonesia
}

\begin{abstract}
The importance of human rights in development is gaining prominence. In concrete settings and contexts, however, contesting development practices with human rights normative standards is controversial. The article outlines this controversy and complexity in Indonesia. It highlights tensions in human rights regulatory frameworks and development policies pertaining to housing and promotion of healthy environment. The main challenge faced by human rights to address development in Indonesia is to understand the complexity of state and market relationship, in designing the process and mitigating the negative impacts of development. Such a complexity is argued to shape the enforcement and susceptibility of international and national human rights laws.
\end{abstract}

Keywords: human rights, right-based approaches, right to housing, right to healthy environment, state-market relationships, development, Indonesia

\section{INTRODUCTION}

As a country stretched along more than 17,000 islands with abundant resources and social diversity, Indonesia is ill-suited to a straightforward process of development. Distribution of progress and benefits, as well as balancing a macroeconomic agenda and protection of human dignity, constitute major challenges.

For decades, Indonesia was administered by an authoritarian regime that disregarded the rule of law and the protection of human rights while delivering economic growth, financial stability and technology transformation. During the New Order government (1966-1998) Indonesia climbed from the ranks of the poorest countries to a solid position among the lower middle-income countries. ${ }^{1}$ The country experienced an average annual economic growth of $7 \%$ in the $1990 \mathrm{~s}$. The absolute poverty line declined from $40 \%$ of the population in 1976 to $11 \%$ in 1996 , and national income increased six fold in real terms. ${ }^{2}$

\footnotetext{
${ }^{1}$ Michael R. J. Vatikiotis, Indonesian Politics Under Soeharto: The Rise and Fall of the New Order (London: Routledge, 2004), p. 34

${ }^{2}$ Bullard, N. et al. 'Taming the Tigers: the IMF and the Asian Crises'. Third World Quarterly. 19 (1998), p. 512; Feridhanusetyawan, T. 'Social Impact of the Indonesian Economic Crisis'. The Indonesian Quarterly. 26 (1998), p. 240.
} 
Although the country ultimately suffered the worst damage in the region from the Asian monetary crisis (1997-1998), which shrunk the economy by 13\%, a recovery is currently well underway. Indonesia now enjoys a reputation as one of fastest growing economies in the world. Its GDP has been growing at an annual rate of $6 \%$ in 2007-2009, and is predicted to continue this positive trend in the future. $^{3}$

The country is also being applauded by the international community for successfully securing democracy and upholding human rights. With a series of peaceful elections (1999, 2004 and 2009) and re-distribution of power from central to local government following the enactment of the Local Autonomy Laws (1999 and 2004), transition from 32 years of authoritarian rule has occurred. The new administrations have been considerably more open to social demands pertaining to the rule of law and human rights. The 1945 Constitution has been amended four times by inserting specific human rights provisions. ${ }^{4}$ The Habibie government (May 1998-October 1999) adopted Law No. 39 of 1999 on Human Rights, and Law No. 26 of 2000 on Human Rights Courts. Additionally, in October 2005, under the administration of Susilo Bambang Yudhoyono (active since October 2004), Indonesia adopted and ratified two important international human rights treaties - the International Covenant on Civil and Political Rights (ICCPR) and the International Covenant on Economic, Social and Cultural Rights (ICESCR).

This progress, one would think, could facilitate ways and means of integrating human rights into development policies. This article aims to depict challenges facing the integration of human rights into Indonesian development processes. To this end, firstly, general debates regarding human rights and development will be discussed. This will be followed by investigating the tensions between human rights and development in Indonesian regulatory frameworks. For empirical analysis, the article will also examine human rights deficits in development policies and the enforcement of human rights legal framework (or the lack thereof) in two cases.

\footnotetext{
${ }^{3}$ World Bank, Indonesia Economy: Strong Performance but Risk Lies Ahead. Avalaible at $<$ http://web.worldbank.org/WBSITE/EXTERNAL/COUNTRIES/EASTASIAPACIFICEXT/IND ONESIAEXTN/0, contentMDK:22860454 pagePK:141137 piPK:141127 theSitePK:226309,00. html > accessed October 12, 2011 at 14.59 .

${ }^{4}$ The 1945 Constitution has been amended four times: October 1999, August 2000, November 2001, and August 2002. Article 28 of the 1945 Constitution (amendment 2002) is devoted solely to human rights principles. This article guarantees a list of the universally accepted human rights, namely the right to freedom of assembly, right to life, right to establish a family, right to personal development, right to be treated equally before the law, right to work and employment, right to religion and freedom to express opinion, right to information, freedom from torture and inhuman and degrading treatment, right to a healthy environment, and right to be free from discriminatory treatment.
} 


\section{SituATING THE DEBATE: HUMAN RightS IN DEVELOPMENT}

The idea that human rights are an integral part of development is widely accepted and internationally acknowledged. ${ }^{5}$ Nonetheless, integrating human rights standards into development processes is inherently a complex enterprise. Development theories do not have the same basis as human rights. ${ }^{6}$ They originated from the work of economists while focusing on the state and macroeconomic phenomena. Consequently, social aspects were secondary, while economic growth and technological transformation were established as goals to measure the process of development. Human rights, on the other hand, are concerned with the protection of people's freedoms and entitlements. It is not just economies that are to be uplifted but people themselves, as actors in their own development. Thus, both living standards and capabilities of those at the grassroots level should be increased.

However, with a rapid flow of economic and financial globalisation, driving both growth and inequality, it seems unrealistic to assume that development would always imply progress in the sense of a structural improvement in people's possibilities to sustain their daily livelihoods. The interactions that govern the process of development have become more complex, involving multiple levels and actors. Tensions and compromises occur in terms of regulations, discourses and/or practices contribute to how development processes are defined and executed. For example, plural laws, values and practices, may be beneficial in accomplishing a state's development agenda, but at the same time they may jeopardise the entitlement position ${ }^{7}$ of people as well. This may imply that benefits of development projects/policies are only enjoyed by some, while others could be negatively affected. Detrimental impacts, particularly on poor and marginalised populations, may become more evident. ${ }^{8}$

Scholarly opinions analysing the complexity in integrating human rights standards in development may be categorised in two methodological streams. The first implies stipulating a set of good practices in development policies or programs, which include express linkages to international human rights law,

\footnotetext{
${ }^{5}$ For example: Kofi Annan, in his report on Renewing the United Nations: A Programme Reform, published on 14 July 1997, states that '[h]uman rights are integral to the promotion of peace and security, economic prosperity, and social equity'. Report of the Secretary General A/51/950, of 14 July 1997 ,

${ }^{6}$ Sano. H. O. 'Development and Human Rights: The Necessary, but Partial Integration of Human Rights and Development', Human Rights Quarterly. 3 (2000)

${ }^{7}$ Sen (1984: 497) defines entitlement as 'the set of alternative commodity bundles that a person can command in a society using the totality of rights and opportunities that he or she faces'.

${ }^{8}$ See supra note 6 .
} 
empowerment, participation, non-discriminations and equality, accountability and attention to vulnerable groups. ${ }^{9}$ The second seeks to establish a binary relationship between an individual as the right-holder and State as the duty-bearer, in which the State is legally accountable to provide remedial actions when it fails to meet its obligations. 10

The first suggests setting out a vision of what ought to be, by stipulating certain practices to guide the implementation of development processes. This methodology is commonly known as 'the rights-based approach to development': a conceptual framework that aims to re-conceptualise traditional development thinking about the process through which development is realised. ${ }^{11}$ The approach describes development not simply in terms of fulfilment to human needs, but in terms of combating human unfreedoms ${ }^{12}$, which thus requires society's obligations to respond to inalienable rights of individuals, empower them to demand their needs, as entitlements and not as a charity. ${ }^{13}$ By incorporating good practice in terms of participation, empowerment or non-discrimination in relevant regulatory and/or policy frameworks, development goes beyond material outcomes, such as meeting basic survival needs, by placing the individual at the centre of the process and enabling them to make their own decisions.

Analysing development processes using the set of good practices provided in the rights-based approach allows for a better understanding of the emergence of human rights violations during its process. Nevertheless, in many developing countries, the defence of human rights in development processes can only be achieved when the declared rights can actually be secured in domestic law and politics. Stressing the legal dimension of state obligations within the process of development, as suggested by the second methodological stream, reflects exactly this concern.

Official commitments and ratifications of international human rights law are assumed to provide a legal basis for citizens to submit claims and possibly to receive compensation for their loss. Reference to human rights in regulatory frameworks should bring about a more stringent dimension to state obligations. Furthermore, human rights declared in (inter)national law have coercive power in domestic jurisdictions to guarantee access to justice for human rights violations in development processes. Human rights violations in development processes and

${ }^{9}$ The Office of the High Commissioner for Human Rights (OHCHR), Renewing the United Nations: A Programme for Reform, UN Doc. A/51/950 of 14 July 1997.

${ }^{10}$ S. P. Marks, (ed). Implementing the Right to Development: The Role of International Law (Geneva: Friedrich-Ebert-Stiftung, 2008), p. 65.

${ }^{11}$ Filmer-Wilson, E. 'The Human Rights-Based Approach to Development: The Right to Water'. Netherlands Quarterly of Human Rights 23 (2005), p. 213.

${ }^{12}$ As argued by Sen in Amarty Sen. Development as Freedom. Oxford: Oxford Univ. Press, 1999.

${ }^{13}$ UNDP, Integrating Human Rights with Sustainable Human Development, UNDP, New York, 1998, para. 173-174. 
outcomes would have legal consequences. Here one talks about justiciability and the enforcement of human rights, particularly regarding the issue of access to justice, entailing rules, regulations, and, if necessary, penalties that can assure compliance of the State, or other third parties. Such an approach to the legal dimension of human rights may be the most important added value in looking at development from a human rights lens. ${ }^{14}$

In this light, the United Nations has set out four possible mechanisms, which are (1) judicial, e.g., judicial review of executive acts and omissions; (2) quasijudicial, e.g., ombudsmen, international human rights treaty bodies; (3) administrative, e.g., the preparation, publication and scrutiny of human rights impact assessments; (4) political, e.g., parliamentary processes. ${ }^{15}$

\section{HUMAN RIGHTS AND DEVELOPMENT IN INDONESIAN REGULATORY FRAMEWORKS}

The new era of governance in Indonesia provides an opportunity for a reorganisation of governmental bodies to become more transparent and accountable. It also provides opportunities for the two methodological streams outlined in the previous section. The enactment of human rights laws and the ratification of international human rights treaties are incorporated in the legal and judiciary systems. Additionally, new rules and regulations with some rights-based approaches are established to organise development processes.

Following the collapse of the New Order, ethnic conflicts and economic depletion spurred demands for a political reform. A specific human rights law was considered an important measure to address conflicts spreading all over the country. ${ }^{16}$ In September 1999, President Habibie signed the Law No. 39 of 1999 on Human Rights.

According to Article 1(1) of the Law, human rights are 'a set of rights bestowed by God Almighty [...] which must be respected, held in the highest esteem and protected by the state, law, Government, and all people in order to protect human dignity and worth'. This law protects the right to be treated

\footnotetext{
${ }^{14}$ Cornwall, A and C. Nyamu-Musembi, 'Putting the 'rights-based approach' to development into perspective'. Third World Quarterly 25 (2004), p. 1417.

${ }^{15}$ The Office of the High Commissioner for Human Rights (OHCHR), Principles and Guidelines for a Human Rights Approach to Poverty Reduction Strategies. 2006, HR/PUB/06/12, Guideline 6.

${ }^{16}$ Hadiprayitno, I. Hazard or Right: the Dialectics Between Development Practice and the Internationally Declared Right to Development, with special reference to Indonesia. Antwerp: Intersentia (2009), p. 142.
} 
equally, right to life, right to justice, right to freedom of the individual with regards to slavery, religious rights, political beliefs, and freedom of speech. With regards to economic, social and cultural rights, the Law guarantees i.e. the right to property and ownership, the right to work, and the right to education.

The Human Rights Law only implicitly addresses human rights protection in development processes. Article 9 stipulates that 'everyone has the right to life, to sustain life, and to improve his or her standard of living'. The terms 'to sustain life' and 'to improve his or her standard of living' could be read to imply that the Law provides protection in processes enabling people to sustain their daily livelihoods. Furthermore, Article 15 asserts that 'everyone has the right to develop himself by individually and collectively protecting his rights, in the interest of developing his society, nation and state'.

Both articles suggest there is some legal protection for human rights violations in development processes in Indonesia. Consequently, a situation where development policies jeopardize people's ability to sustain their daily livelihood and/or their standard of living could be considered as an infringement to these two articles. Whether this means that people would be able to seek remedy for their sufferings and there would be an independent court to treat their cases depend on the jurisdiction of national courts.

The system of claims and remedies for human rights is regulated in the Law No. 36 of 2000 on the Human Rights Court. Articles 4 and 7 of the Human Rights Court Law asserts the authority of the Human Rights Court to hear and rule on cases of gross violations of human rights, which include the crime of genocide and crimes against humanity. The Human Rights Court, however, does not have jurisdiction over violations of other rights guaranteed in the Human Rights Law No. 39 of 1999. Consequently, some rights recognised in the Human Rights Laws, i.e. the right to work, the right to food, the right to health, the right to housing, or right to improve one's standard of living, cannot be claimed in the Human Rights Court.

This implies the State could not be held legally accountable for failures to respect, protect or fulfil its obligations with regard to these rights. Such a procedural deficit may establish a situation of ambiguity for those seeking to address negative impacts of development process as human rights violations.

Other and more recent legal provisions are also relevant to explain how human rights are integrated into the national system of development processes, particularly pertaining to rights-based approaches standards such as participation, accountability and transparency. The Law No. 25 of 2004 on the National System of the Development Process gives general guidelines for the process of development in Indonesia. Article 2(1) stipulates that togetherness, justice, sustainability and independence are the governing principles, which means that development requires not only macro involvement of all governmental functions, 
but also needs to serve the unity of the country. Furthermore, Article 8 stipulates development in Indonesia as a set of processes of construction and decisionmaking, as well as monitoring and evaluation, based on the principles of consensus and deliberation.

Adherence to the principles of transparency and openness is articulated in the adoption of Law No. 32 of 2004 on Local Autonomy, which was introduced to decentralise political and economic power away from New Order's centralised rule. One main provision in the Law is the abolition of the former clear-cut hierarchical relationship between central, provincial and district government. Decentralisation involves transferring of political, fiscal and administrative powers from the central government to lower administrative levels. ${ }^{17}$ Dependency for revenue from the central government decreases as provincial and district governments are given the authority to manage investment, supply of taxes and public service provision. As such, district government, according to Article 14, Law No. 32 of 2004, is now responsible for the implementation and daily operations of activities in education, health, culture, public works and the environment.

Theoretically, decentralisation or local autonomy opens up possibilities for participation for the people to articulate their concerns and interests in development directly to the local government and to become actors in their own development. Shifting authority and responsibilities for numerous administrative functions to the local level should bring government closer to the people, which could make development process more accountable. The adoption of rights-based approaches' principles in the law could mean that people and other stakeholders may expect changes in how resources and outcomes being governed and measured. It also implies that people can apply rights-based approaches' principles in across the board, as processes and outcomes. As argued before, if the rights-based approach is not sufficient, one would need a more rigorous instrument to mitigate negative impacts of a development process suffered by poor and vulnerable people. For further analysis of the challenges in applying these two methodological streams, the following sections will discuss human rights deficits in development policies and the complexity in addressing human rights violations in development.

\footnotetext{
${ }^{17}$ Duncan, C. R. 'Mixed Outcomes: The Impact of Regional Autonomy and Decentralisation on Indigenous Ethnic Minorities in Indonesia’. Development and Change. 38 (2007).
} 


\section{Human Rights Deficits in Development Policies}

This section is set out to examine the process in which development is realised from the rights-based approach to development. The deficits in such a process may be distinguished into policies/programs with limitations due to resources, policies/programs that have been shanghaied by corruption or vested interest and policies/programs that actually begin with a foundation in human rights. The examination covers two specific areas relevant to adequate standard of living, viz. the right to housing and forced eviction as well as the right to healthy environment and management of toxic waste.

\section{A. Right to Housing and Forced Evictions}

Article $28(\mathrm{G})$ and $28(\mathrm{H})$ of the 1945 Constitution respectively assert the protection of the right of everyone's property and the right to have a home. Law No. 39 of 1999 on Human Rights also guarantees the right to housing in Article 36 and 37. Article 36 stipulates that no one shall be subjected to arbitrary or unlawful seizure of their property. When a property must be destroyed or abandoned, either permanently or temporarily for the purpose of public interest, Article 37 stresses that compensation shall be paid in accordance with prevailing legislation, unless otherwise decreed. Lastly, the right to housing is envisaged in Law No. 4 of 1992 which affirms the right to occupy and/or enjoy and/or own a decent house in a healthy, safe, harmonious and orderly environment.

Despite these favourable legal provisions, the main issues in Indonesia are housing resources and government involvement managing the different stakeholders in housing businesses. According to the recent data collected by Habitat for Humanity, Indonesia needs to provide roughly 735,000 new houses per year. ${ }^{18}$ This number is unlikely to be met because the housing programmes are not widely accessible or spread. In Indonesia the housing prices and supplies are determined by market fluctuations since private companies are the important actors in this area.

With respect to the first reason, the home loan national programme (Kredit Pemilikan Rumah - KPR) is accessible only for those living in urban areas. In rural areas, there is no assistance in terms of housing development. This programme assigns banks to provide home loans with below market interest rates.

18 Estimation is provided by the Habitat for Humanity Office Jakarta, http://www.habitat.org/intl/ap/95.aspx, accessed April 19, 2010, at 12.12. 
The procedure is similar to common mortgage regulations, but in Indonesia there are no further appraisals conducted on the real value of houses. Furthermore, as access to this programme requires a secure employment position, those without a job have no option but to independently or illegally build their houses.

This leads to the second reason; because construction and supplies are not regarded as governmental business, housing availability in Indonesia is connected with market situations. They are managed by private developers associated with the Indonesia Real Estate Association (Real Estate Indonesia or REI). This organisation is responsible for $70 \%$ of housing supplies and the semi-government housing developer, Perum Perumnas (Perusahaan Umum Perumahan Nasional).

Such a dominant role of private companies in the housing situation in Indonesia is confirmed by the statement coming from the Ministry of Settlements and Regional Infrastructure representative. It is mentioned that 'development of housing carried out by the community, particularly the low-income community, is self-supportedly encouraged and developed under the quality and quantity enhancement guidance'. ${ }^{19}$ The argument behind this strategy is to empower citizens by comprehensively positioning the community as the main actor with the government acting as an enabler and facilitator and active participant in private business.

The rather limited involvement of State in the housing policy in Indonesia leads to a meagre protection in the right to housing for the poor. This is manifested in the quality of the housing in general. The World Health Organisation (WHO) defines a house as being in good shape when it provides a minimum floor area of $10 \mathrm{~m}^{2}$ per person. As to this recommendation, the Indonesian Central Bureau for Statistics reported that in 2008 only around 59.6\% of households occupied floor areas of more than 50 square metres. ${ }^{20}$ The remaining $40.4 \%$ refers to poor condition houses, such as the slums and illegal houses subject to Government eviction programmes. This survey, however, ignores the number of inhabitants living in the houses.

The second concern regarding the right to housing in Indonesia is the recourse mechanism. There are no explicit laws to formally grant people access to claim or seek compensation, particularly in cases of forced eviction. The right to housing in Indonesia is challenged by the implementation of Presidential Regulation 36/2005 on the Provision of Land for the Implementation of Public Interest Development.

The Decree excuses the practice of eviction for public purposes. It widens the scope for revoking land titles and acquiring land for public projects by not

\footnotetext{
${ }^{19}$ Priyono, G. Housing Industry in Indonesia. Unpublished paper, presented in the Seminar of ASEAN Association for Planning and Housing (AAPH), Manila June 2002, p. 4

${ }^{20}$ Indonesian Bureau for Statistical Analysis and Development (BPS). Statistik Indonesia. Jakarta: BPS, 2008, p. 85.
} 
providing sufficient elaboration on the concept of 'public purposes', which is meagrely defined as the interest of majority. Compared with the previous regulation (Presidential Decree No. 55 of 1993), which stipulated public interest in terms of government activities and government ownership, and not commercial purposes, this is a retrogressive measure.

Moreover, the Decree threatens the access to land and livelihoods of the poor, particularly living in slum areas. It provides for compensatory programmes for those affected but only for those landowners who carry land certificates, are in possession of complete documentation and agree with the proposed compensation package, which is based on the selling price of taxed properties, documented below market price. Regarding the enforcement of measure, the Special Rapporteur on the Right to Housing reported in that although landowners shall have the right to complain within a set time frame if they do not agree with the proposed compensation, the relevant authorities retain the power to immediately evict people whilst the case is pending in court. ${ }^{21}$ An example is the case of forced eviction in Karang Anyar Jakarta explained later in this article.

\section{B. Right to Healthy Environment and Management of Toxic Waste}

The entitlement to live in a healthy environment is recognised as a human right in Article $28(\mathrm{H})$ of the 1945 Constitution. Under the heading of the right to life, Article 9 of the Law No. 39 of 1999 on Human Rights guarantees the right to an adequate and healthy environment.

A contemporary challenge regarding the right to healthy environment in Indonesia is the management of toxic waste. According to Article 1 of Government Regulation No. 18 of 1999 on Management of Toxic Waste, toxic waste is the residue of a business and/or any activities that contain hazardous or toxic materials that because of its nature, concentration and/or amount, either directly or indirectly, can damage and/or endanger life and the environment, health, human survival and other living creatures.

An example of the problem of toxic waste in Indonesia is on controlling mercury uses and releases in artisanal and small-scale gold mining (ASGM). A written statement by the International NGO Forum on Indonesian Development (INFID) at the UN sessions highlights that ASGM is a complex issue with poverty at its heart. In Indonesia, about 700-800 ASGMs are spread out all over the country mainly using mercury to get the gold out of the ore. The whole ore

${ }^{21}$ Human Rights Council, Report of the Special Rapporteur on the right to adequate housing as a component of the right to an adequate standard of living, Mr. Miloon Kothari, A/HRC/4/18/Add.1, 18 May 2007, p. 15 
amalgamation process practiced by ASGM in Indonesia released mercury into the atmosphere and the environmental as well as to the workers. In one ASGM site, mercury released into the atmosphere could reach up to 50 ton a year, leading to a serious threat to human health and the environment. ${ }^{22}$

In assessing the human rights deficit in the process of development pertaining to the issue of healthy environmentm, it is of particular interest to examine the performance of state agencies in monitoring the compliance of private companies within the context management of toxic waste. Some regulations on oil and natural gas exploration have set clear guidance regarding the scope of duties and responsibilities of state agencies, which can be incorporated in order to safeguard the enjoyment of the right to a healthy environment.

Law No. 18 of 2008 on Waste Management is adopted with the aim to improve public health and the quality of environment and to facilitate ways to develop waste as a resource. It is the responsibility of central and local government to ensure that waste management considers the protection and promotion of the environment, as stipulated in Article 5. In this light, cooperation between local governments is encouraged. Article 11 affirms the entitlement of everyone to obtain services in waste management and to participate in its decision making process. According to Article 25, relocation, environmental rehabilitation and health costs are the possible forms of compensation available for victims issued by local and central government.

The problem of toxic waste in Indonesia has received considerable attention at the international level. On 14 August 2009, an allegation letter was jointly sent by UN Special Rapporteurs on the adverse effects of toxic wastes, on the right to food, on the right to health and on the right to housing to the Government of Indonesia. The letter points out the negative impacts of gold and copper mining activities in Lembata, East Nusa Tenggara, have regarding access to safe drinking water and sanitation. ${ }^{23}$ Of particular concern is the lack of information regarding social, environmental and health impacts, and the scanty measures taken to ensure that the mining project does not have disproportionate negative impacts on the environment and on the communities.

The list of concerns is a reflection that the promotion and protection of right to a healthy environment is challenged with lack of participation, transparency and accountability of state agencies in managing the business activities of private

22 Human Rights Council, Written statement submitted by the International NGO Forum on Indonesia Development (INFID), a nongovernmental organization in special consultative status, A/HRC/15/NGO/68, 6 September 2010, p. 4

23 Human Rights Council, Report of the Special Rapporteur on the adverse effects of the movement and dumping of toxic and dangerous products and wastes on the enjoyment of human rights, Okechukwu Ibeanu, A/HRC/15/22/Add.1, 2 September 2010, p. 15 
stakeholders. As to accountability, one could actually refer to the Executing Agency for Upstream Oil and Gas Activity (Badan Pelaksana Kegiatan Hulu Minyak dan Gas Bumi/BP MIGAS), which according to Article 41(2) of Law No. 22 of 2001 on Petroleum and Natural Gas, is in charge of the supervision over the implementation of business activities. BP MIGAS is authorised to control the overall operational management, including the approval of working and budgetary plans, field development plans as well as supervision over the realisation of said plans.

Nevertheless, the absence of explicit provisions that require BP MIGAS to monitor the changes in the ownership of the company that holds the right of 'participating interest' (or the exploration right) within the joint cooperation contract scheme can be considered as the primary weakness of the current supervision mechanism. With the lack of participation and information regarding environmental impact of business activities, the low performance of state agencies in monitoring the compliance of private companies with the existing laws and regulations may be considered to be the primary concern in this regard, which will be further discussed in the case of Hot Mud tragedy later in this article.

\section{Development from Above}

The foregoing discussion highlights the delicate balance between the roles of the state agencies and private actors in the process of development in Indonesia, and the inconsistency in the bodies of national regulatory frameworks that suggests government's central role in designing development policies while at the same time asserts the importance of participation, transparency and accountability. The adoption of laws that may infringe on the realisation of human rights and the lack supervision in monitoring the process and outcome of development policies are argued here as non-compliance actions and an example of a retrogressive measure in realising human rights.

From a human rights perspective, negative impacts of development could be prevented or redeemed through a rooted practice of participation, transparency and accountability. However, it is observed that in Indonesia development processes and outcomes are arranged by involving private stake-holders. Their contribution may be considered necessary for creating a favourable environment for macro-economic development. To this end, normative assertions of good practices in development of participation, accountability and transparency are framed to assist State's intervention in favour of the accumulation of capital and political stability, rather than facilitating people to become main actors or the centre of the development process. Decentralisation, which aims to transfer the 
power from the central to the local government, leads to a cornucopia of laws aiming at the formalisation of roles and responsibilities of various state agencies; a puzzle that people may need to solve before exercising participation or demanding transparency and accountability.

The way in which the relationship between state agencies and other stakeholders is developed demands adaptations and adjustments to the rightsbased approaches to development. The excretion of power of private stake-holders and the ambitions to achieve an enabling environment for macro-economic growth and to secure political stability require the State to adopt an adaptive role. ${ }^{24}$ Only in the complexity of multi-level and multi-stakeholder negotiations concerning the rights-based approaches and basic needs, is the State in a position to simultaneously participate in different arenas and to selectively transpose conditionalities asserted in legal frameworks to development. At the same time, moreover, the State employs selective strategies to avoid their obligations promote human rights. Such an intricate relationship between the State and multistakeholders in development processes establishes a vulnerable position for people.

\section{Actual Implications to Human Rights Claims: Two Case STUDIES}

The complexity of laws and actors in negotiating the process of development in Indonesia implies that one would need a more stringent methodology. The declared human rights provisions in the 1945 Constitutions and in Law No. 39 of 1999 on Human Rights need to be legally enforceable, meaning that there should be an independent court to treat the cases, whose judgments are honoured by the State and private stakeholders. Yet, this complexity of laws and actors also leads to more challenges in applying a legal dimension of state obligations of international and national human rights in the process of development.

The following case studies examine this particular concern, while at the same time analyse the outcomes of the actions to combat negative impacts of development, taken by either the State as principal duty-bearer or the people as the right-holders.

${ }^{24}$ S. Randeria, 'Glocalization of Law: Environmental Justice, World Bank, NGOs and the Cunning State in India'. Current Sociology 51 (2003). 


\section{A. The Case of Forced Eviction in Karang Anyar, Jakarta}

Karang Anyar was a poor kampung that emerged after the economic crisis of 1998. It was located beneath the train fly-over in Sawah Besar municipality, Jakarta. Approximately 265 families lived in an area of 4 ha and mostly worked as street vendors, becak drivers, drudges or coolies and bin collectors. This kampung was considered an illegal habitation because officially they occupied land owned by the State Train Company (Perusahaan Jaringan Kereta Api or PJKA). Housing conditions were semi-permanent; the houses were built using recycled woods and other materials. Generally, this type of area is common in urban cities such as Jakarta, and the houses are considered transit houses built by those who are disadvantaged and cannot access proper housing because of their lack of income. The daily income of people living in the area was 10,000-15,000 IDR or less than a dollar a day, which explains their insufficient material basis for proper housing. ${ }^{25}$

The introduction of an eviction plan for Karang Anyar began on $6^{\text {th }}$ September 2000, when invitations for a closed meeting were circulated to certain prominent figures living in the area. Attended by the head of the municipality and the heads of the neighbourhood group, it was agreed that the people should be cleared from the area within a period of two days, while by $9^{\text {th }}$ September 2000 fences would be built as the area was intended for small shop buildings. On $11^{\text {th }}$ November 2001, the local government evicted people from this area while the population demonstrated at the Regional House of Representatives.

At that time, Presidential Decree No. 55 of 1993 governed the procurement or acquisition of land for public interest and development projects. Based on the stipulated provisions, some clear violations in the case of Karang Anyar were observed. The first concerned the issue of consent. The Decree stated that the process of land acquisition should be conducted based on the informed consent of the inhabitants, ${ }^{26}$ meaning that they must be informed and that a process of deliberation must take place. As explained, in this case the population were not given a sufficient introduction to the eviction plan, since the information was only distributed to a few selected representatives.

The second violation was related to the objective of the eviction plan. The Decree stated that land acquisition is legal only for the purpose of public interests, which includes public markets, roads, etc. ${ }^{27}$ Business oriented shops owned by

\footnotetext{
${ }^{25}$ According to The Governor Decree of Jakarta No. 302 of 2001. In 2007 according to Decree of the Governor Jakarta No. 1734 of 2006, the minimum wage in Jakarta is 900.560 IDR.

${ }^{26}$ Article 4 and 5, Presidential Decree No. 55 of 1993.

27 The definition of public interests includes development of roads, dams, hospitals, harbours, religious buildings, schools, markets, cemeteries, post and telecommunications infrastructures,
} 
private companies certainly could not be categorised as public markets and thus they did not fall under the definition of public interests. Additionally, this objective is also incongruent with Article 37 of Human Rights Law No. 39 of 1999, which stipulates that land acquisition can take place only when the objective of the action is for public interest.

Another problem in the case of Karang Anyar was that the compensation paid for land and other assets was less than the market value. Yet, this might not entirely be considered as a violation to the Presidential Decree No. 5 of 1993. The Decree merely provided general provisions on a procedure for land acquisitions and compensations according to the tenure status and ownership rights, lacking provisions on resettlement and restoration of the income and livelihoods of the project-affected people. On the other hand, Article 37 of the Human Rights Law asserts that fair, proper and adequate compensation is to be allocatedduring land acquisition and restoration. In the case of Karang Anyar, the population was given 300,000 IDR per family as compensation. In this respect, one can observe a violation of the right to property as stipulated by Human Rights Law No. 39 of 1999. Of course, it can be argued that given the illegal housing status of the population, such compensation would be considered sufficient; yet, one should also bear in mind that their disadvantaged status and vulnerability were also caused by their economic, political and social status in society which conditioned them to be restricted to such a standard of living.

In an attempt to assert their entitlement positions and with the assistance of civil society organisations, the Urban Poor Consortium and the Indonesian Legal Aid Foundation (Yayasan Lembaga Bantuan Hukum Indonesia or YLBHI), along with the victims of the Karang Anyar eviction, lodged their case with the Regional House of Representatives, the Department of Infrastructure, and the Ministry of Housing. Following a series of demonstrations, 43 inhabitants of Karang Anyar submitted a class action suit to the Regional Court of Jakarta against the Governor of Jakarta, the Head of the Central Jakarta Region, the State Train Company and the Regional Police force. After 36 sessions at the Central Jakarta Regional Court, Judge Andi Samsan Nganroe ruled that the action of the Jakarta government to evict those people from their houses was a tort and hence the Government should bear the responsibility of compensating the victims. The Court ordered material compensation of 30,540,000 IDR and immaterial compensation of 20,500,000 IDR. $^{28}$ The decision was based on the information that the land acquisition had taken place not for the purpose of public interests, but for personal and business

sports facilities, radio or television stations, government and military offices. Article 5, Presidential Decree No. 55 of 1993 on Regulation of Acquisition of Land for Public Interest.

${ }^{28}$ The compensation ranged from 25,000 to 3.5 million IDR; generally each person would receive 500,000 IDR. 'Hakim Menangkan Gugatan Korban Penggusuran', Koran Tempo, January 20, 2002. 
interests, which therefore required a judiciary process of acquisition rather than a public process by using governmental powers.

In response to this decision, the Regional Government of Jakarta appealed to the High Court of Jakarta. The representative of the regional government said that this response was taken to maximise the available legal resources. ${ }^{29}$ Currently the case is still pending; however, the execution of a class action lawsuit and litigation showed that a remedy is possible so as to concretely recognise hitherto unacknowledged freedoms and entitlements.

\section{B. The Case of the Hot Mud Tragedy in Sidoarjo East Java}

The Hot Mud tragedy started on $29^{\text {th }}$ May 2006 when hydrogen-sulfide gas (H2S) was reported to be leaking from a gas exploration rig in Sidoarjo, operated by Lapindo Brantas Inc (LBI). It happened during company drilling activities in search of natural gas deposits in the Banjar Panji-1 exploration site in Renokenongo village, Sidoarjo district, East Java. The gas leak spurted 10 metres high from cracks in the ground and was followed by hot mud spraying 100-150 metres high, reaching as far as the residence area nearby. ${ }^{30}$

The upwelling of hot mud created a large pool of mud, rendering the neighbourhood uninhabitable and causing people to flee from their homes. In addition, the intercity turnpike to the East Java capital Surabaya had to be closed down for weeks. ${ }^{31}$ The explosion wrapped 4 villages in the Porong region in 6 metres of mud. From the data gathered by the Department of Health prior to $20^{\text {th }}$ June 2006, the mud explosion drowned 71.7 hectares of paddy field, 16.3 hectares of industrial terrain, 7.9 hectares of housing area, and 8 hectares of public facilities. The data also recorded approximately 3,825 people evacuated to the refugee post in Pasar Baru Porong.

On $27^{\text {th }}$ August 2006, President Susilo Bambang Yudoyono declared the 400-hectare area affected by the mudflow in Porong, Sidoarjo district a disasterprone area unfit for human habitation. As of $12^{\text {th }}$ April 2007, the National Development Planning Board estimated that the total loss caused by the mudflow within the period of nine months after the first eruption had reached 27.4 trillion

\footnotetext{
29 'Kalah Digugat Warga Korban Penggusuran, Pemda DKI Naik Banding', Kompas, January, 11, 2002

30 Badan Penelitian dan Pengembangan Departemen Kesehatan RI. Survey Cepat Dampak Semburan Lumpur Panas di Kecamatan Porong, Kabupaen Sidoarjo Jawa Timur. Department of Health of the Republic of Indonesia Survey Report. Jakarta (2006), p. 6.

${ }^{31}$ WALHI, WALHI's Position Paper PT Lapindo Brantas Mud and Gas Leak, Report, 18 July 2006
} 
IDR. Another effect of this explosion was environmental damage and health risks suffered by the population. From the research performed by the Centre for Environmental Health Technology (Balai Besar Teknik Kesehatan Lingkungan BBTKL) in Surabaya, it was observed that the quality of the air had deteriorated as it contained a high amount of manganese - 5 times the level of manganese recommended by Regulation Ministry of Health No. 416 of 1990.

The mud was also observed as dangerous, since it had amalgamated with other fluids coming from industrial waste from the factories in the surrounding area. $^{32}$ The research also noted a high amount of fenol in the formation of the mud, which was assumed to be generated by a decomposition of various processes within the earth. The BBTKL warned that this environmental deterioration might lead to chronic health risks for the population; they might experience haemoglobin damage or cardiac arrhythmia. Direct contact with the contaminated mud might cause skin burns or rashes. ${ }^{33}$ As of $20^{\text {th }}$ June 2006 , the number of patients taken into care in the medical posts and hospitals in the area numbered 4,463 patients. They suffered from, for example, gastritis, diarrhoea, cephaligia, and dermatitis.

Speaking at a parliamentary hearing, LBI executives told legislators that the Yogyakarta earthquake of the $27^{\text {th }}$ May 2006was responsible for causing the leak to its exploration site that triggered the mud eruption at the first place. On the other hand, Friends of the Earth Indonesia (Wahana Lingkungan Hidup Indonesia or WALHI) contended that the disaster was purely the failure of the LBI's exploration team to install what is known as 'safety casing' around the exploration well to the levels required under the general standard operational procedure in natural gas extractive industries. WALHI's allegation was supported by a letter from LBI's partner company, Medco Energy, confirmed the LBI's negligence for not installing the protective casing in the Banjar Panji-1 well to an adequate depth of 8,500 feet as agreed in its joint operating agreement. The claim was sustained by the findings of a geologist research team from the University of Durham in the UK (Davis et al, 2007:1), which found that the mud eruption was caused by the failure of the company's drilling team to comply with the standard safety procedure by using a steel casing to protect the well at high pressures during drilling at 2,830 metre depth.

This particular case attracted heavy criticism concerning the poor performance of BP MIGAS in enforcing and monitoring the implementation of Indonesian mining regulations by a private company. As the investigation by WALHI revealed, BP MIGAS did not take any action regarding previous violations of Indonesian laws and regulations by LBI.

\footnotetext{
${ }^{32}$ The formation of the mud shows the high amount of chemical oxygen demand (COD) exceeding the number recommended by the Decree of Ministry of Health No. Kep-42/MenLH/10/1996.

${ }^{33}$ Badan Penelitian dan Pengembangan Departemen Kesehatan RI (2006) p. 12-13.
} 
Of particular interest is the fact that LBI did not disseminate the information regarding their exploration activities to the nearby residents prior to commencing the drilling process on its exploration sites. This is a clear violation of Article 33 (1) of Government Regulation No. 27/1999 on Environmental Impact Analysis and the Minister of Mining Circular Letter No. 1462/20/DJP/1996, in which BP MIGAS should have noticed its duty to monitor the conduct of a private company in the oil and gas extractive industry. ${ }^{34}$ Furthermore, failures to provide necessary protection was also committed by the Government. The study of the Indonesia Centre for Environment Law (ICEL) revealed that both Government and private firms continue to block public access to information about environmental problems, which exacerbates ecological disasters in the country.

On $8^{\text {th }}$ December 2006, a civil action to claim against human rights violations, including the right to healthy environment, was brought to the State Civil Court in Central Jakarta by the Indonesian Legal Aid Foundation (Yayasan Lembaga Bantuan Hukum Indonesia - YLBHI). On $27^{\text {th }}$ December 2007, the Court ruled that no human rights violations are committed by the government nor LBI. $^{35}$ While the Judges acknowledged negligence committed by LBI in complying to the standard safety regulations, the Ruling Judge Moefri was of the opinion that maximum efforts have been done in ensuring minimum damages are experienced by the people living in the disastrous area. In fact, The Court has maintained the opinion that Yogjakarta earthquake is the cause of the mudflow Despite to convincing testimony of geologist. ${ }^{36}$

In response to this disappointment, some victims have brought their cases to the Indonesian National Commission of Human Rights, followed by an investigation in 2008. On $24^{\text {th }}$ February 2009, the Commission declared adversities occurred in the Sidoardjo Hot Mud Tragedy that were gross violations of human rights, based on the findings that at least 15 economic, social and cultural rights were violated during the displacement process. If accepted, this declaration implies following investigations to be taken by the state attorney and the case can be brought to the Indonesian Human Rights Court.

\section{Development without Protection}

Development has the general connotation of a structural improvement of people's well-being. In practice, however, it often affects the livelihoods of its beneficiaries

\footnotetext{
${ }^{34}$ WALHI, Lumpur, Kesengajaan atau Kelalaian? Case Report. 28 July 2006

35 'PN Kalahkan Korban Lumpur', Kompas, 28 November 2007

${ }^{36}$ Keputusan Pengadilan Negeri Jakarta Pusat No. 384/PDT.G/2006/PN.Jktpst. Para. 245 and 225229.
} 
in a negative way. Two cases from Indonesia demonstrate this very concern. From a human rights perspective, a similarity in both cases is the failure of the State to meet its obligation to protect.

Obligation to protect is a type of state obligation that requires active protection against other, more assertive or aggressive subjects - more powerful economic interests. ${ }^{37}$ The state obligation to protect human rights in development cannot simply be regarded as merely requiring the State to establish measures to prevent third parties from violating human rights. In fact, the specific designation of state obligations to protect is to determine what should be done by whom at a level of detail that will permit assessment of compliance by responsible agents themselves and, where appropriate, by others charged with supervision over their compliance. ${ }^{38}$ Hence, the State is responsible for accelerating the adjudicative exercise in holding the perpetrators of the violation of human rights accountable. Since the violation of human rights may occur from the failures of the State in ensuring the compliance of third parties with the existing laws and regulations, such legal action must include prosecuting the officials of the state agencies who failed to discharge their duties to secure the implementation of those laws by third parties.

The two cases illustrate exactly how the state obligation to protect depends on the process and outcomes of judiciary exercises. As observed, the right-holders are now able to demand government accountability through legal actions, either within the framework of human rights law or not. Indeed, the inclusion of human rights provisions and/or the rights-based approach's principles in normative legal frameworks is indispensable in facilitating this development.

Yet, in the case of Indonesia, the promise as to whether this could bring about changes in development process is distant. The government continues to be reluctant to take political risks for the supremacy of human rights law or the inclusion of people. One explanation may be that such a commitment would jeopardise the authority of the Government by exposing those government officials who are mostly involved in errant practices when taking decisions on development. It is feared that an emphasis on the human rights-based entitlements in the development process could harm the bureaucratic machine and slow the process of macroeconomic development. Hence, human rights, particularly those relevant to development processes, have become constitutional rights, but they have not become rights in the domestic legal system

\footnotetext{
${ }^{37}$ Absjørn Eide, Updated Study on the Right to Food, UN doc. E/CN.4/Sub.2/1998/9, 29 June 1998, Para. 9.

${ }^{38}$ Shue, H. 'The Interdependence of Duties'. In. P. Alston and K. Tomasevski (eds). The Right to Food. Doordrecht: Martinus Nijhoff Publisher, 1984, p. 84
} 


\section{CONCLUDING REMARKS}

In the view of the transition to democracy, which was initiated about a decade ago, Indonesia embraces a new era of openness. A redefinition of development processes were demanded along with distribution of power. Participation, transparency and accountability are the selected vocabularies that represent the change. The actual intricacies between State and private actors in designing development policies and programs, particularly those related to housing and healthy environment, however, show that transition can primarily be found in the position of the government. The incorporation of 'the rights-based approach' in development does not mark a shift in terms of peoples inclusion; it is rather a transmission of government control and influence in collaboration with other stake-holders in the development processes. The actual arrangement of distribution of benefits shows persistence vulnerability with regards to people's actual access to development policies.

The ratification of International Convention on Economic, Social and Cultural Rights in 2005 and the adoption of the Law No. 39 of 1999 on Human Rights suggest that the Government of Indonesia is prepared to be held accountable to human rights claims and is willing to incorporate the values of human rights in designing the country's development policies. However, the discussion in this article reveals that human rights are not instrumental in designing and assessing the process and outcomes of development. Laws and regulations that oppose the protection of human dignity continue to be issued and implemented. From a legal perspective, this occurs due to the lack of justiciability and enforceability of human rights laws in development policies. Unavoidably, human rights laws and the rights-based approaches standards serve merely as palliatives to protect victims and combat the negative impacts of development.

Against such a complexity, facing challenges to integrate human rights in the development in Indonesia demands an understanding of whether the failures of protecting the poor and vulnerable are actually resulting from the lack of commitment to enforce human rights, or the evolution of the State's role in adapting to new conditions or rules of the game for policymaking according to human rights standards. The main concern here is whether the incorporation of human rights provisions and the rights-based approaches in national legal frameworks concerning development is actually a way in which the State may employ strategies to avoid enforcing human rights laws.

Civil society organisations as accountability agents may be expected to continue taking the lead in advocating that official commitments in national laws and, more importantly ratifications of the international human rights treaties should deliver its impact. Improving the situation may require progressive 
translations of domestic human rights laws, for example by interpreting crimes against humanity as to include violations of economic, social and cultural rights, as practice by the National Commission of Human Rights. A strenuous effort as such may be able to invite workable negotiations, and yet inescapable for the State and private actors, at different levels of governance.

\section{REFERENCES}

Ahmed, I. Indonesia's Crisis and Recovery: the Myths and Reality, unpublished paper, presented in the discussion at the International Labour Organization, Jakarta, ILO, April 2000

Albert, J.and Slengesol, I. Education in Crisis: Impact and Lessons of the East Asian Financial Shock, 1997-1999 (Washington DC: The World Bank, 2000).

Andreassen, B. and S.P. Marks. Development as a Human Rights (Boston: Harvard School of Public Health, 2006).

Badan Penelitian dan Pengembangan Departemen Kesehatan RI. Survey Cepat Dampak Semburan Lumpur Panas di Kecamatan Porong, Kabupaen Sidoarjo Jawa Timur (Jakarta: Department of Health of the Republic of Indonesia, Survey Report. 2006).

Beeson, M. and V. Hadiz. 'Labour and Politics of Structural Adjustment in Australia and Indonesia'. Journal of Contemporary Asia. 28 (1998).

Davies, R.J. et al, 'Birth of a Mud Volcano: East Java, 29 May 2006', GSA Today 17, 2007

De Gaay Fortman, B. 'In Search of a New Paradigm: Development Interventionism from a Human Dignity Perspective'. In O. Salemink et al (eds). The Development of Religion, the Religion of Development (Delft: Eburon, 2004).

Cornwall, A and C. Nyamu-Musembi, 'Putting the 'rights-based approach' to development into perspective'. Third World Quarterly 25 (2004).

Duncan, C. R. 'Mixed Outcomes: The Impact of Regional Autonomy and Decentralisation on Indigenous Ethnic Minorities in Indonesia'. Development and Change. 38 (2007).

ELSAM - IDEA, Dampak Kebijakan IMF pada pemenuhan hak atas bekerja, pendidikan dan kesehatan di Indonesia (Jakarta: ELSAM-IDEA, 1999).

Filmer-Wilson, E. 'The Human Rights-Based Approach to Development: The Right to Water'. Netherlands Quarterly of Human Rights 23 (2005). 
Friends of Earth. The Kalimantan Border Oil Mega Project, Report of Friends of Earth the Netherlands and the Swedish Society for Nature Conservation. April 2006.

Friends of Earth, Life Mosaic and Sawit Watch. Loosing Ground: The Human Rights Impact of Oil Palm Plantation Expansion in Indonesia. Executive Summary. February 2008.

Hadiprayitno, I. Hazard or Right: the Dialectics Between Development Practice and the Internationally Declared Right to Development, with special reference to Indonesia (Antwerp: Intersentia 2009).

Hamm, B.I. 'A Human Rights Approach to Development'. Human Rights Quarterly 23 (2001).

Indonesian Bureau for Statistical Analysis and Development (BPS), Crisis, Poverty and Human Development in Indonesia, 1998 (Jakarta: BPS, 1999).

----, Statistik Indonesia. Jakarta: BPS, 2008.

Keating, G.C. 'Distributive and Corrective Justice in the Tort Law of Accidents'. Southern California Law Review. 74 (2000).

Marks, S. P. (ed). Implementing the Right to Development: The Role of International Law. Geneva: Friedrich-Ebert-Stiftung, 2008.

Mulholland, J.P. and Thomas, K. 'The Price of Rice', Inside Indonesia, 58 (1999).

Orford, A. 'Globalisation and the Right to Development'. In P. Alston (ed). Peoples Rights (Oxford: Oxford Univ. Press, 2001).

Priyono, G. Housing Industry in Indonesia. Unpublished paper, presented in the Seminar of ASEAN Association for Planning and Housing (AAPH), Manila June 2002

Randeria, S. Glocalization of Law: Environmental Justice, World Bank, NGOs and the Cunning State in India Current Sociology 51 (2003).

Sano. H. O. 'Development and Human Rights: The Necessary, but Partial Integration of Human Rights and Development', Human Rights Quarterly. 3 (2000).

Sen, A. Resources, Values and Development (Oxford: Blackwell,1984).

Sengupta, A. 'On Theory and Practice of the Right to Development', Human Rights Quarterly. 24 (2002).

Shue, H. 'The Interdependence of Duties'. In. P. Alston and K. Tomasevski (eds). The Right to Food. (Doordrecht: Martinus Nijhoff Publisher, 1984).

Skoufias, E. and Suryadi, A. Growth and Crisis Impacts on Formal Sector Wages in Indonesia, SMERU Working Paper, December 1999.

The World Bank, Report and Recommendations of the President of the International Bank for Reconstruction and Development to the Executive Directors on a Proposed Social Safety Net Adjustment Loan in the Amount of US\$600 million to the Republic of Indonesia. Report No. P7307-IND, The World Bank, 1999. 
Urban Poor Consortium, Kisah Bantaran Rel Karang Anyar, Study Report, 4 December 2005.

Vatikiotis, Michael R. J. Indonesian Politics Under Soeharto: The Rise and Fall of the New Order (London: Routledge, 2004).

Warr, P. 'Food Policy and Poverty in Indonesia: A General Equilibrium Analysis', The Australian Journal of Agricultural and Resource Economics 49 (2005).

WALHI, WALHI's Position Paper PT Lapindo Brantas Mud and Gas Leak, Report, 18 July 2006.

WALHI, Kasus Lapindo, Fakta Kegagalan Supremasi Hukum. Case Report, 28 November 2006.

WALHI, Lumpur, Kesengajaan atau Kelalaian? Case Report. 28 July 2006. 